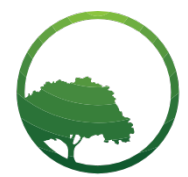

Research in Business \& Social Science

IJRBS VOL 8 NO 5 ISSN: 2147-4478

\title{
Influence of human resource planning on performance of firms listed in the Nairobi Securities Exchange in Kenya
}

\author{
Dorcas Kiai ${ }^{a *}$, Peter Lewa ${ }^{b}$, James Karimi ${ }^{c}$ \\ ${ }^{a, b, c}$ School of Business, United States International University, P.O. Box 14634 - 00800, Nairobi, Kenya
}

Crossref

\begin{tabular}{l} 
A R T I C L E IN F O \\
\hline Article history: \\
Received 14 July 19 \\
Received in revised form 30 \\
Accepted 02 August 19 \\
\hline Keywords: \\
Human resource planning \\
Firm performance, \\
Nairobi Stock Exchange \\
JEL Classification: \\
O15 \\
M14
\end{tabular}

\begin{abstract}
A B S T R A C T
The study sought to determine the influence of human resource planning on firm performance of firms listed in the Nairobi Securities Exchange in Kenya. The study was anchored on human capital theory and shareholder value maximization theory. The research design used was a cross-sectional survey while the study population constituted all the 68 listed firms at the Nairobi Stock Exchange (NSE) as in May 2017. The target population included the head of human resources and finance directors in all the listed firms. The sample size comprised of 136 respondents, and data was collected through structured questionnaires to meet the objectives of the study. Responses were tabulated, coded, and processed by the use of a computer Statistical Package for Social Science (SPSS) to analyze the data. Both descriptive and inferential statistical techniques were used to analyze the data. To test hypotheses, a simple linear model was used to test significance between the independent and dependent variable. The study findings revealed that the relationship between human resource planning and firm performance was positive and statistically significant and hence rejected the null hypothesis. The study concluded that the type and strategy of the firm, succession planning, matching skills with jobs and skills inventory are human resource planning indicators influencing the performance of firms listed in the NSE. It is therefore recommended that firms should continue to practice and maintain adequate human resource planning as it plays a fundamental role in achieving the objectives of the organizations.
\end{abstract}

(C) 2019 Bussecon International Academy. Hosting by SSBFNET. All rights reserved. Peer review under responsibility of Bussecon International Academy \& SSBFNET.

\section{Introduction}

Human resources are regarded as one of the most important resources of today's firms. The main purpose of human resource management is to improve business performance through people management. So as to achieve the set goals and objectives, organizations ought to manage their human resources effectively and efficiently (Luftim, 2014). Human resource management strategies reflect the philosophy of senior management with regard to treatment of human resources and address the various activities related to their management (Mwatete, 2012). The underlying premise of this is that the human resource function supports corporate goals by developing and implementing people management practices which engage employees and encourage them to direct their efforts towards the achievement of organizational goals. Hence, the most tangible aspect of strategic human resource management is the set of human resource policies and processes in existence in a firm and how they address various aspects of people management such as recruitment, diversity, management development, reward and employment relations (Foot \& Hook, 2008).

Human resource planning (HRP) is concerned with proactively analyzing the external environment and making the best possible use of employees (Badejo, 2015). According to Fajana (2002) planning is done with reference to the task and contextual environment of organization. HR planning is critical to the effective employee career development as it identifies gaps and surpluses in capabilities as well as issues of utilization of talent. HR planning must identify the knowledge, skills, abilities, experience, and characteristics affecting the capabilities of employees for current and future jobs (Mathis \& Jackson, 2008). Redman and Wilkinson (2009) noted

\footnotetext{
* Corresponding author. Tel: +254-730-116000/300 ORCID ID: 0000-0003-1529-9888
} Peer review under responsibility of Bussecon International Academy. (C) 2019 Bussecon International. Hosting by SSBFNET- Center for Strategic Studies in Business \& Finance. All rights reserved. https://doi.org/10.20525/ijrbs.v8i5.310 
that with the decline of careers in some firms, HRM techniques such as performance appraisal have become more important managerial tools in motivating and controlling the workforce. Employees are increasingly being appraised not only on objective measures such as productivity and quality but also on more subjective aspects such as dependability, flexibility and loyalty (Badejo, 2015). The firms listed on the NSE compete in a dynamic business environment that affects their performance (Sagwa et al., 2015). The firms have to formulate and implement sound and strategic HRM Practices in order to make optimum use of a workforce that can make the firms build a sound human resource base that is sustainable. Human resource planning (HRP) is a crucial process in every organization and therefore very essential to conduct human resource planning (HRP) since hiring the wrong employees or failure to anticipate fluctuations in hiring needs could be costly in the long run. The process of HRP ensures that, an organization's employees have the requisite skills and competencies an enterprise needs for it to succeed (Ghazala \& Habib, 2012). Ngui et al., (2014) adds that, HRP prepares appropriately employees for potential rationalization. It further enables a firm to make adequate preparations for recruitment and strategic hiring. According to Mursi (2013), there exists a significant and positive relationship between HR planning and firm performance. Hiti (2010) showed that HR planning has a positive relationship with firm performance. Further, Arsad (2012) indicated that manpower planning affects firm performance and have a positive relationship between manpower planning on firm performance. Study by Chand and Katou (2017) in the Indian hotel industry also found out that manpower planning have strong relationship to productivity, and productivity impact on firm performance. Suitable HRP enhance organizational effectiveness leading to increased output by identifying, attracting, and retaining manpower with the required knowledge, talents and capabilities and getting them to behave in a manner that will support the mission and predetermined objectives (Osman et al., 2011).

This study was conducted to question if there was influence of human resource planning on performance of firms which are listed in the Nairobi Securities Exchange. The study sought to answer the question: What is the influence of human resource planning on performance of firms which are listed in the Nairobi Securities Exchange? The objective was to determine the influence of human resource planning on performance of firms which are listed in the Nairobi Securities Exchange in Kenya. Very few studies have evaluated the influence of human resource planning on performance of firms and the few that have been done have taken place in developed countries and mostly outside Africa. The study sought the opinions of HR managers and finance directors in the 68 firms registered in the NSE. The results of this study may be beneficial to firms that are aiming to be listed in the Nairobi Securities Exchange to analyze the human resource planning that they apply in their firms and aim to have sustainable ones that may improve the firm performance and consequently get them listed. The regulators and the policy makers can use the findings of the study to formulate viable policy documents on human resource planning that effectively address problems faced by the organizations in Kenya. These may relate to regulating those aspects that threaten to adversely impact on the operations and development of such organizations.

\section{Literature Review}

\section{Human resource planning}

Moyo (2015) did a study with the aim of finding out the contribution of human resources planning in public institutions performance. The major findings show that poor planning of HR has an impact on organization performance as the response from the respondents shows inadequate priority for HRP; there exist a lot of problems during process of HRP as insufficient top management support, insufficient funds, as well as shortage of expertise. The study concluded that Human Resource Planning has strong relationship with the performance of a particular Institution. Thus effective HRP leads to good performance and in ineffective HRP leads to poor performance of a particular Institution. A study to determine the key determinants of formal human resource planning that contributes towards performance in the telecom sector was carried out by Afzal et al. (2013). The data collected from top managers, middle level managers and the first line HR managers of 50 offices including head offices and regional offices of 160 questionnaires including some interview and open ended questions based on the measures of performance and Human Resource Planning. The results from the factor analysis on HRP measures selection, training and incentives and the organizational performance measures which were job satisfaction, efficiency, employee motivation and technology constituted significant and a positive relationship with each other. The study concluded that as modern HR practices are implemented in telecom sector and companies would spend more on human resources, it would lead towards high performance achievement. A research on human resource planning practice in managing human resource was conducted by Aslam et al., (2013). From the study findings it is evident that human resource planning is gaining importance in the business community. Because of inflation and weak economic conditions, profits are shrinking, effective human resource planning process is considered much important to enhance production without wastage and with minimum staff requirements to save costs. Opoku (2012) carried out an analysis of human resource planning and its effect on organizational effectiveness. The results of the study revealed that most of the information services department staff did not have in-depth knowledge on Human Resource Planning, thus is not well practiced by the senior officers. The study concludes with the organization being proactive in recruiting and retaining employees.

A study to identify the influence of human resource planning (HRP) on organizational performance of fast food companies in Port Harcourt was conducted by Tende \& Alagah (2017). The findings from the ascertainment of the influence of forecasting demand on increased productivity revealed that there is a positive influence of forecasting demand on increased productivity at 0.611 , when the $\mathrm{p}$-value $<.01$ which is $<0.05$. The findings from the ascertainment of the influence of forecasting demand on increase in sales revealed that there is a positive influence of forecasting demand on increase in sales at 0.877 , when the p value $<.01$ which is $<0.05$. 
The study concluded that the need for proactive HRP calls on organizations especially fast food companies to enhance their performance through and adhere strictly to forecasting HR or manpower needs, while taking constructive strategic actions through its HRP policies; noting that appropriate HRP sequence of action(s) (or activities)are taken into consideration when proactively forecasting HR needs and enhancing increased productivity which result in increase in sales as this will boost overall performance at every point in the life of the organization. A study on the relationship between human resource planning and organizational performance was carried out by Pamela et al. (2017). 5(five) firms were selected using stratified sampling technique in oil and gas firms in Port Harcourt. The Taro Yamane was used to determine the sample size which aggregate of 70 managers and supervisors was derived. Using the spearman rank order correlation coefficient, there was a significant relationship between human resource planning and organizational performance and that the relationship between the variables was moderated by organizational structure. The study recommended that oil companies and their human resource managers should continually carryout manpower audit and planning to determine in advance the demand and supply situation in the labor market prior to recruitment of employees.

\section{Firm performance}

Kinyugo (2014) investigated the effect of cost efficiency and financial performance of companies listed in the Nairobi Securities Exchange in Kenya, The 60 companies listed in the Nairobi Securities Exchange formed the population of the study. The sample consisted of 47 companies listed in the NSE who had published financial data which was available continuously over the sample period of the study 2008 to 2013 . The research adopted a descriptive survey design. The study utilized secondary sources of data. In order to situate the study theoretically and generate the conceptual framework with which to work on the secondary sources was obtained from financial statements and NSE Handbooks of the companies for a 6 year-period (2008-2013) and publications were also used. The findings established that assets management measures demonstrate how efficient management uses a firm's assets to generate sales over a certain period of time. Asset management ratios showed how efficiently and intensively assets are used to create Revenue efficiently and intensively. A study examining the determinants of firm profitability for 114 firms listed on the Nigerian Stock Exchange (NSE) from 1998 to 2012, using the system Generalized Method of Moments (GMM) was done by Yinusa (2018). The results showed that lagged profitability exerts significant positive effect on contemporaneous firm profitability. However, shortterm leverage, inflation rate, interest rate and financial risk have significant negative effects on firm profitability. The study suggested among other recommendations, that the cost of borrowing to the real sector of the economy should be reduced in order to minimize costs of production, enhance productivity and profitability while necessary macroeconomic policies should be put in place by the government to curb inflationary pressure in the economy. Mohd and Hoshino (2013) did an empirical research which aimed to investigate the performance by analyzing sales growth ratio and profitability ratio in ICT industry between Japan and three ASEAN countries. Data from Orbis Database (OVBD) were analysed; 24 ICT companies in ASEAN region which consist of Thailand, Malaysia, and Philippines; and 69 ICT companies in Japan by using $t$ test technique. The findings revealed that Japan and ASEAN had no significant difference with each other in their sales growth performance. Meanwhile, ASEAN shows better performance in profitability when comparing with Japan in ICT industry. A study aimed at determining the effect of sales growth on the financial performance of listed Agricultural Companies at Nairobi Securities Exchange in Kenya from 2003 to 2013 was done by Odalo (2016).The study was anchored on the theory of the firm growth that recognizes that increments in sales over the years affects financial performance of an organization. A panel design with descriptive and causal study design was adopted and all the listed companies in the agriculture sector in Kenya were studied. Sales increments in each year was used as a measure of sales growth while financial performance was measured by return on assets (ROA), return equity (ROE) and earnings per share (EPS). Inferential statistics (correlation and regression) was used for data analysis. A pooled OLS regression model was used to incorporate the time and space movements. The study affirmed that sales growth had a positive and significant effect on financial performance measures ROA and ROE and negative and insignificant effect on EPS.

The relationship between efficiency and financial performance of commercial banks in Kenya was examined by Ngunyu (2013). The research adopted a descriptive survey design. The population of interest for this study was all the commercial banks in Kenya. Thus it was a census survey. The study utilized secondary sources of data. In order to situate the study theoretically and generate the conceptual framework with which to work on the secondary sources was obtained from financial statements of the banks for a 5 yearperiod (2007-2012) and publications were also used. From the findings, there was a fall in efficiency ratio from 2008 to 2012 in banks indicating that the banks were making considerably more than they were spending thus depicting a sound fiscal footing. The findings revealed a significant positive relationship between Return on Asset and Efficiency.

\section{Research and Methodology}

This section included the methodology that was used and includes the research sampling design, the sample size and data analysis. This was a census study which involved obtaining information from every member of the population, therefore no sampling was done. Census study has advantages in that the confidence level is increased and it is easy to identify negative feedback if any in the information given (Babbie, 2012). The study collected data from all the 68 listed firms at the NSE. The study involved all human resources managers and finance directors hence no sampling was done for those categories making a sample size was 136 respondents. Data was collected using semi-structured questionnaires, comprised of open-ended and closed-ended questions, developed by the researcher. Collected data was taken through data analysis phases which involved data clean up, reduction, differentiation and explanation. Data cleanup involved editing, coding and tabulation in order to detect any anomalies in the responses 
and also assign specific numerical values to the responses for further analysis. Data was then keyed using Statistical Package for Social Sciences (SPSS) with appropriate codes and variable specification after which counter checking was done to ensure no erroneous entries. Descriptive statistics was used for measures of central tendencies including mean, and standard deviation. Pearson $r$ was used in this study since the data was measured in the interval scale and Pearson's correlation coefficient technique is recommended for such data as being the most appropriate for determining relationships (Kothari, 2004). To test hypothesis, simple linear model was used to test significance between the independent and dependent variable where the significance level for hypotheses testing was set at 0.05 .

\section{Discussions and Findings}

\section{Descriptive statistics for human resource planning}

The study further sought to find out the respondents' level of agreement with the following statements on influence of human resource planning on firm performance. The findings are tabulated in Table 1.

Table 1: Descriptive statistics for human resource planning

\begin{tabular}{|c|c|c|c|c|c|c|c|c|}
\hline & $\begin{array}{l}\text { Strongly } \\
\text { Disagree } \\
(\%)\end{array}$ & $\begin{array}{l}\text { Disagree } \\
(\%)\end{array}$ & $\begin{array}{l}\text { Neutral } \\
(\%)\end{array}$ & $\begin{array}{l}\text { Agree } \\
(\%)\end{array}$ & $\begin{array}{l}\text { Strongly } \\
\text { Agree } \\
(\%)\end{array}$ & Mean & SD & Rank \\
\hline $\begin{array}{l}\text { HRM policies and practices help } \\
\text { employees to develop and exploit their } \\
\text { potential maximally }\end{array}$ & 0.0 & 0.0 & 14.2 & 9.4 & 76.4 & 4.62 & 0.72 & 1 \\
\hline $\begin{array}{l}\text { HRM policies and practices treat } \\
\text { employees fairly and equitably }\end{array}$ & 0.0 & 12.6 & 7.1 & 7.1 & 73.2 & 4.41 & 1.07 & 4 \\
\hline $\begin{array}{l}\text { HRM policies, processes, practices } \\
\text { support overall organizational } \\
\text { strategy }\end{array}$ & 0.0 & 4.7 & 12.6 & 10.2 & 72.4 & 4.50 & 0.89 & 2 \\
\hline $\begin{array}{l}\text { Employees have access to grievance } \\
\text { systems }\end{array}$ & 0.0 & 7.1 & 13.4 & 32.3 & 47.3 & 4.20 & 0.93 & 5 \\
\hline $\begin{array}{l}\text { Great amount of socialization and } \\
\text { induction of new employees }\end{array}$ & 3.9 & 17.3 & 10.2 & 29.1 & 39.4 & 3.83 & 1.24 & 8 \\
\hline $\begin{array}{l}\text { Extensive formal training for all levels } \\
\text { of employment }\end{array}$ & 0.0 & 10.2 & 11.0 & 37.0 & 41.7 & 4.10 & 0.97 & 6 \\
\hline $\begin{array}{l}\text { The working environment is warm, } \\
\text { supportive and pleasant }\end{array}$ & 2.4 & 6.3 & 9.4 & 8.7 & 73.2 & 4.44 & 1.05 & 3 \\
\hline $\begin{array}{l}\text { HRM policies, processes, practices } \\
\text { have long term perspective }\end{array}$ & 3.1 & 11.0 & 4.7 & 48.0 & 33.1 & 3.97 & 1.05 & 7 \\
\hline $\begin{array}{l}\text { Hiring of new employees is done } \\
\text { mainly at job entry levels }\end{array}$ & 26.0 & 18.1 & 16.5 & 23.6 & 15.7 & 2.85 & 1.44 & 10 \\
\hline Jobs are flexibly designed & 4.7 & 11.8 & 16.5 & 36.2 & 30.7 & 3.76 & 1.15 & 9 \\
\hline
\end{tabular}

Source: Authors

The results in Table 1 indicate that, majority of HR and Finance Directors strongly agreed with the statements that: HRM policies and practices help employees to develop and exploit their potential maximally (76.4\%), HRM policies and practices treat all employees fairly and equitably (73.2\%), The working environment is warm, supportive and pleasant (73.2\%), and HRM policies, processes, practices support overall organizational strategy and objectives (72.4\%) as statements regarding influence of human resource planning on firm performance. However, $26.0 \%$ of the respondents strongly disagreed that Hiring of new employees is done mainly at job entry levels $(26.0 \%)$ as a statement regarding influence of human resource planning on firm performance. The findings further reveal that the statements HRM policies and practices help employees to develop and exploit their potential maximally had the highest means of 4.62 and was ranked first while Hiring of new employees is done mainly at job entry levels was ranked last with a mean of 2.85 .

\section{Descriptive statistics for human resource planning}

The study sought to find out the respondents' level of agreement on how the indicators given had improved firm's performance in the firms listed at the NSE in Kenya. The findings are tabulated in Table 2. 
Table 2: Descriptive statistics for firm's performance in Kenya

\begin{tabular}{|c|c|c|c|c|c|c|c|c|}
\hline & $\begin{array}{l}\text { Strongly } \\
\text { Disagree } \\
(\%)\end{array}$ & $\begin{array}{l}\text { Disagree } \\
(\%)\end{array}$ & $\begin{array}{l}\text { Neutral } \\
(\%)\end{array}$ & $\begin{array}{l}\text { Agree } \\
\text { (\%) }\end{array}$ & $\begin{array}{l}\text { Strongly } \\
\text { Agree } \\
(\%)\end{array}$ & Mean & SD & Rank \\
\hline Market share & 5.5 & 3.1 & 7.1 & 57.5 & 26.8 & 3.97 & 0.983 & 3 \\
\hline Cost reduction & 2.4 & 10.2 & 11.0 & 26.8 & 49.6 & 4.11 & 1.107 & 2 \\
\hline Sales growth & 2.4 & 7.1 & 13.4 & 48.0 & 29.1 & 3.94 & 0.962 & 4 \\
\hline Efficiency of growth & 6.3 & 8.7 & 21.3 & 37.8 & 26.0 & 3.69 & 1.139 & 6 \\
\hline Continuous staff training & 0.0 & 5.5 & 18.9 & 33.9 & 41.7 & 4.12 & 0.905 & 1 \\
\hline Profitability & 7.1 & 11.0 & 8.7 & 33.1 & 40.2 & 3.88 & 1.251 & 5 \\
\hline
\end{tabular}

\section{Source: Authors}

The results in Table 2 indicate that, majority of respondents strongly agreed that cost reduction (49.6\%), continuous staff training $(41.7 \%)$, profitability $(40.2 \%)$ had improved firm's performance in in the firms listed at the NSE in Kenya. The findings further reveal that cost reduction and profitability had the highest means of 4.12 and 4.11 respectively. Efficiency of growth had the lowest mean of 3.69.

\section{Correlation between human resource planning and firm performance}

Pearson correlation coefficient is a measure of linear association between two variables. Values of the correlation coefficient are always between -1 and +1 . A correlation coefficient of +1 indicates that two variables are perfectly related in a positive linear sense whereas a correlation coefficient of -1 indicates that two variables are perfectly related in a negative linear sense. On the other hand, a correlation coefficient of 0 indicates that there is no linear relationship between the two variables (Kothari, 2004). According to Cohen (1988) interpretation of correlation coefficients, 0.00 to 0.01 shows no correlation; 0.02 to 0.09 show very weak correlation; 0.1 to 0.29 show weak correlation; 0.30 to 0.49 show moderately weak correlation; 0.5 to 0.69 show moderately strong correlation; 0.70 to 0.89 show strong correlation; 0.90 to 0.98 show very strong correlation while 0.99 to 1.00 show almost perfect correlation. Table 3 shows the correlation between human resource planning and firm performance.

Table 3: Correlation Analysis between human resource planning and firm performance

\begin{tabular}{llll}
\hline Firm Performance & Pearson Correlation & Firm Performance & HR Planning \\
\hline & Sig. (2-tailed) & 1 & \\
\hline N & Nearson Correlation & 127 & 1 \\
\hline & Sig. (2-tailed) & $.817^{* *}$ & .000 \\
\hline
\end{tabular}

** Correlation is significant at the 0.01 level (2-Tailed)

Source: Authors

The correlation coefficient $(\mathrm{P})$ between firm performance and HR Planning was found to be 0.817 at $(\mathrm{P}=0.000)$. These results indicate that according to the study, there was a highly significant linear correlation between the two variables (HR planning and firm performance). This implies that the relationship between the two variables is very close. A relationship therefore exists since it is above the recommended 30\% (Mugenda \& Mugenda, 2003). This supports the argument by Afzal et al., (2013) who found that as modern HR practices are implemented in the study sector and companies would spend more on Human Resources, it would lead towards high performance achievement. They argue that if HR planning is conducted in an objective and professional manner, then it is likely to improve firm performance. Lupton (2000) indicated that firm performance and human resource planning are positively related since organizations with desired levels of staff will have adequate workload for them, thus enhance their performance. Rye and Paterson (2001) indicate that employees doing the right jobs usually determined through human resource planning tend to be more productive. 


\section{Inferential statistics}

There is no significant relationship between human resource planning and firm performance of firms listed in the Nairobi Securities Exchange was the study's hypothesis.

The null hypothesis was tested using the following linear regression model:

$y \neq \mathrm{a}+\mathrm{b}_{1} X_{1}+\mathrm{e}$

Where:

$y$ - Performance of NSE firms

a-Constant Term

$b_{1}-$ Regression Coefficient

$X_{1}$ - Human Resource Planning

$\mathrm{e}-$ Error Term

Results in Table 4 show the summary of the regression model applied in this study. The study findings show that $r$ is equal to 0.817 , indicating that human resource planning has a great influence on performance of firms listed in the NSE. The value of R squared is 0.668 , indicating that human resource planning explains $66.8 \%$ of the variation in the performance of firms listed in the NSE.

Table 4: Model summary

\begin{tabular}{lllll}
\hline Model & R & R Square & Adjusted R Square & Std. Error of the Estimate \\
\hline $\mathbf{1}$ & 0.817 & 0.668 & 0.665 & 0.40824 \\
\hline
\end{tabular}

a. Predictors: (Constant), human resource planning

Source: Researcher data (2018)

To test for the level of significance of the regression model, ANOVA was used and the results in Table 5. The ANOVA results gave a significance of 0.00 showing that the study's regression model was significant tested at $95 \%$ level of significance. The overall $\mathrm{F}$ statistic was $(1,125)=251.059$ with $\mathrm{p}=0.000<0.05$ suggesting that there existed a statistically significant relationship between human resource planning and performance of firms listed in the NSE.

Table 5: ANOVA

\begin{tabular}{lllllll}
\hline Model & & $\begin{array}{l}\text { Sum of } \\
\text { Squares }\end{array}$ & df & Mean Square & F & Sig. \\
\hline $\mathbf{1}$ & Regression & 41.841 & 1 & 41.841 & 251.059 & 0.000 \\
\cline { 2 - 7 } & Residual & 20.832 & 125 & 0.167 & & \\
\cline { 2 - 7 } & Total & 62.673 & 126 & & & \\
\hline
\end{tabular}

a. Predictors: (Constant), human resource planning

b. Dependent Variable: Firm performance

Source: Researcher data (2018)

The Beta ( $\beta$ ) coefficient for human resource planning is 1.072 (Table 6). The $\beta$ values imply that one unit change in performance of firms listed in the NSE is associated with $107.2 \%$ change in human resource planning. The results indicate that human resource planning statistically significantly influences on the performance of firms listed in the NSE $(\beta=1.072, t=15.845, p=0.000<0.05)$.

Using the statistical findings, the regression model can be substituted as follows:

$y=-0.411+1.072 X_{1}$

This can be interpreted to mean that a unit change in human resource planning causes a positive change of 1.072 on firm performance. Based on the research findings, we reject the null hypothesis which stated that there is no significant relationship between human resource planning and performance of firms listed in the NSE and conclude that human resource planning has a statistically significant influence on the performance of firms listed in the NSE. 
Table 6: Regression Results of effect of human resource planning on firm performance

\begin{tabular}{|c|c|c|c|c|c|c|}
\hline \multicolumn{7}{|c|}{ Coefficients } \\
\hline \multirow{2}{*}{\multicolumn{2}{|c|}{ Model }} & \multicolumn{2}{|c|}{ Unstandardized Coefficients } & Standardized & \multirow[t]{2}{*}{$\mathrm{t}$} & \multirow[t]{2}{*}{ Sig. } \\
\hline & & $\mathrm{B}$ & Std. Error & Beta & & \\
\hline \multirow[t]{2}{*}{1} & (Constant) & -0.411 & .278 & & -1.480 & .141 \\
\hline & HR Planning & 1.072 & .068 & .817 & 15.845 & .000 \\
\hline
\end{tabular}

a. Dependent Variable: Firm performance

Source: Authors

\section{Discussions and Implications}

\section{Research Implications}

The study established the influence of human resource planning on the firms listed in the NSE in Kenya. The findings revealed that human resource planning positively influence firm performance. Janes (2018) also established that there was a significant relationship between human resource planning and organizational performance. Proficient HR in organizations provides competitive advantage and the actual and appropriate management of human capital may be the ultimate determining factor for the performance (Ricardo \& Wade, 2011). It is critical that the researchers gain an understanding on the human resource planning strategies and practices and thoroughly examine and understand them in the case of firms listed in the Nairobi Securities Exchange. The findings of this study have managerial implications as they inform the managers of firms aiming to be listed in the Nairobi Securities Exchange the human resource planning applicable in their firms and the sustainable ones that may improve the firm performance and consequently get them listed. Further, regulators and the policy makers can use the findings of this study as reference for policy guidelines on management and control of such firms and therefore can formulate viable policy documents on human resource planning that effectively address problems faced by the firms in Kenya. These may relate to regulating those aspects that threaten to adversely impact on the operations and development of such firms.

\section{Conclusions}

The study was conducted to establish the influence of human resource planning on the firms listed in the NSE in Kenya. The study specifically looked at the HRM policies and practices that help employees to develop and exploit their potential maximally, that treat all employees fairly and equitably, practices that support overall organizational strategy and objectives and the working environment being warm, supportive and pleasant are significant aspects of HR planning that influence the performance of firms. They were found to significantly influence firm performance. The study demonstrated that it is important for firms to continue practicing and maintaining effective human resource planning as it plays fundamental role in achieving performance of firms. Future research should focus on policies and practices that will ensure that there is succession planning increases the availability of experienced and capable employees that are prepared to assume roles as they become available and therefore firms need to create a solid succession plan. It is also important for firms listed in NSE to ensure that they match their employees' skills with jobs and that they have a skills inventory which will help strategic planning efforts.

\section{References}

Afzal, F., Mahmood, K., Sherazi, S. M. R., Sajid, M., \& Hassan, M. (2013). Effect of human resource planning on organizational performance of Telecom Sector. Information and Knowledge Management, 2, 173-182.

Arsad, M. (2012). Human Resource Management Practices and Organizational Performance: A study on Administrators in Universiti Teknologi Mara. (Unpublished MSc Dissertation). Universiti Utara Malaysia.

Aslam, H., Aslam, M., Ali, N., Habib, B., \& Jabeen, J. (2013). Human Resource Planning Practice in Managing Human Resource: A Literature Review. International Journal of Human Resource Studies, 3(1), 200-212.

Babbie, E. R. (2012). The Practice of Social Research (13 ${ }^{\text {th }}$ Ed.). Cengage Learning

Badejo, A. E. (2015). Strategic Human Resource Management Practices and Employees' Career Development in Selected Commercial Banks in Lagos State, Nigeria. European Journal of Business and Management, 7(2), 83-95

Chand, M., \& Katou, A. A. (2017). The impact of HRM practices on performance in the Indian hotel industry. Employee Relations, 29(6), 576 594. https://doi.org/10.1108/01425450710826096

Cohen, J. (1988). Statistical Power Analysis for the Behavioral Sciences (2nd ed.). Hillsdale, NJ: Lawrence Erlbaum Associates, Publishers.

Fajana, S. (2002). Human Resources Management: An Introductory, Lagos: Labofin and Company.

Foot, M. \& Hook C. (2008). Introducing Human resource Management (5 $5^{\text {th }}$ Ed.). Pearson Education UK. https://trove.nla.gov.au/work/8239226

Ghazala, I., \& Habib, J. (2012). Human Resource Strategies. Journal of Business and Management, 3(6), 6-13.

Hiti, K. A. (2010). Human Resource Management: A strategic Entrance, Oman: Dar Hamid Library. 
Janes, O. (2018). Human Resource Planning as an Important Practice to Anticipate Future Human Resource Requirements of the Organization - Literature review. International Journal of Research in Business Studies and Management, 5(3), 24-30

Kinyugo, J. M. (2014). The Effect of Cost Efficiency on Financial Performance of Companies Listed on Nairobi Securities Exchange. Research Project, University of Nairobi.

Kothari, C. K. (2004). Research Methodology Methods and Techniques, (2 ${ }^{\text {nd }}$ Ed.). New Delhi. New Age International (P) Limited Publishers.

Luftim, C. (2014). The Impact of Strategic Human Resource Management on Organizational Performance, Economia. Seria Management, 2, 374-380.

Lupton, B. (2000). Pouring the coffee at interviews? Personnel's role in the selection of Doctors. Personnel Review, $29(1), 48-64$. https://doi.org/10.1108/00483480010295817

Mathis, R. L. \& Jackson, J. H. (2008). Human resource management (12th Ed.). South Western, United States: Centage Learning.

Mohd, F. M. S., \&Yasuo, H. (2013). Sales Growth, Profitability and Performance: Empirical Study of Japanese ICT Industries with Three ASEAN Countries. Interdisciplinary Journal of Contemporary Research in Business, 20(1), 138-156

Moyo, N. J. (2015). The Contribution of Human Resources Planning in Public Institutions Performance: A Case Study of Mlele District Council. Research Dissertation, University of Tanzania

Mugenda, O. M. \& Mugenda, A. G. (2003). Research Methods, Quantitative and Qualitative Approaches. ACT, Nairobi.

Mursi, J. (2013). The strategic management of human resources: The entrance to achieve Competitive advantage to joining the twenty-first century. Alexandria: University House.

Mwatete, L. K. (2012). Challenges of Implementing Strategic Human Resource Management at the Kenya Sugar Board. Research Project, University of Nairobi

Ngui, T.K., Elegwa, K., \& Hazel, G.G. (2014). Effect of employee resourcing on the performance of commercial banks in Kenya. International Journal of Education Research, 2(1), 1-20.

Ngunyu, P. I. (2013). Relationship between Efficiency and Financial Performance of Commercial Banks in Kenya. Research Project, University of Nairobi

Odalo, S. K., Njuguna, A. G., \& Achoki, G. (2016). Relating Sales Growth and Financial Performance in Agricultural Firms Listed In the Nairobi Securities Exchange in Kenya. International Journal of Business, Economics and Management, 4(7), 443-154

Opoku, Y. (2012). An analysis of human resource planning and its effect on organisational effectiveness: a case study of information services department, Accra office. A published Thesis, Kwame Nkrumah University of Science and Technology.

Osman, I., C. F. Ho, T, \& Galang, M. C. (2011). The relationship between human resource practices and firm performance: An empirical assessment of firms in Malaysia. Business Strategy Series, 1, 41-48

Pamela, A. C., Umoh, G. I., \& Worlu, G. (2017). Human Resource Planning and Organizational Performance in Oil and Gas Firms in Port Harcourt. International Journal of Advanced Academic Research, 9, 110-129

Redman, T., \& Wilkinson, A. (2009). Contemporary human resource management : text and cases', 3rd edn.

Richard, O. (2009). 'Racial diversity, business strategy, and firm performance: A resource-based view'. Academy of Management Journal, 43, 164-177.

Rye, T., \& Paterson, C. (2001). 'The partnership approach to mobility management: An evaluation of different models for travel planning by groups of employees'. Paper presented at the ECOMM.

Sagwa, E., K'Obonyo, P., \& Ogutu, M. (2015). 'Human Resource Management Practices and Performance of Firms Listed on the Nairobi Securities Exchange'. DBA Africa Management Review, 7(14), 124-136

Tende, F., \& Alagah, A. D. (2017). Influence of Human Resource Planning On Organizational Performance of Fast Food Companies in Port Harcourt, Nigeria. Imperial Journal of Interdisciplinary Research (IJIR), 3(11), 458-467. http://www.onlinejournal.in

Yinusa, O. (2018). Determinants of Firm Profitability in Nigeria: Evidence from Dynamic Panel Models, 68. 